\title{
Morphology, reproduction, habitat use, and hibernation of Red-bellied Snake (Storeria occipitomaculata) near its northern range limit
}

\author{
Nicholas A. Cairnsi, ${ }^{1,}$, Pamela L. Rutherford ${ }^{1, ~ *}$, and Drew J. Hoysak ${ }^{1}$ \\ ${ }^{1}$ Department of Biology, Brandon University, 270 18th Street, Brandon, Manitoba R7A 6A9 Canada \\ ${ }^{2}$ Department of Biology, Queen's University, 116 Barrie Street, Kingston, Ontario K7L 3N6 Canada \\ ${ }^{*}$ Corresponding author: rutherfordp@brandonu.ca
}

Cairns, N.A., P.L. Rutherford, and D.J. Hoysak. 2018. Morphology, reproduction, habitat use, and hibernation of Red-bellied Snake (Storeria occipitomaculata) near its northern range limit. Canadian Field-Naturalist 132(2): 150-162. https:// doi.org/10.22621/cfn.v132i2.2054

\begin{abstract}
Northern regions limit ectotherms to relatively short periods of feeding and breeding interrupted by long periods of inactivity. This may force cool-climate ectotherms into different ecological or demographic trade-offs than their southern conspecifics. Our aim is to examine demography, morphology, reproduction, habitat use, and hibernation by populations of Red-bellied Snake (Storeria occipitomaculata) near their northern range limit. This research was conducted in southwestern Manitoba and data on summer activity were collected from April to September 2007-2009 using coverboard and pedestrian surveys. Hibernation sites were monitored over three winters (2007-2008, 2008-2009, and 2009-2010), and thermal profiles of Formica ant mounds were collected in 2008-2009 and 2009-2010. Females reached sexual maturity at a smaller size than most other populations that have been reported but appear to have similar clutch sizes to the rest of the range. The majority of adult females captured at our summer sites were gravid (96\%) suggesting annual reproduction, and activity patterns suggest fall breeding. Near its northern range maxima, this species appears to use relatively warm habitat, have rapid reproduction, and co-opt ant mounds to survive in a difficult climatic environment. Much remains unknown and future studies should further examine the variation in size at maturity and the relationship between body size and clutch size. In addition, little is known about diet, benefits of fall mating, use of open prairie habitats, and late-season migration by $S$. occipitomaculata.
\end{abstract}

Key words: Red-bellied Snake; Storeria occipitomaculata; cool-climate; temperate; Manitoba; thermoregulation; brumation

\section{Introduction}

Regions with extended cold seasons present challenges for many ectothermic species, which is reflected by the limited species diversity of snakes and other squamates at higher latitudes (Kiester 1971). These regions have short summers and long, cold winters that limit individuals to relatively short periods of feeding and breeding interrupted by long periods of forced inactivity (Gregory 2009). Because short active seasons can limit the time available to allocate resources, coldclimate individuals may have different ecological tradeoffs than their lower latitude conspecifics (Gregory 2009). As such, aspects of growth (Blouin-Demers et al. 2002), reproduction (Gregory 2009), and habitat use (Weatherhead et al. 2012) can differ within species across a range, reflecting local selective pressures (Fitch 1981).

Sexual size dimorphism (SSD) has been examined in numerous snake species (reviewed in Shine 1994). Sexual size dimorphism is common but can vary geographically with northern populations. They are often less dimorphic than southern populations which is often attributed to phylogenetic conservatism (Shine 1994; Cox et al. 2007). Size at maturity can be conserved across the range of most species, but the age at which an individual reaches mature size may be more plastic (Blouin-Demers et al. 2002). Cold-climate reptiles are expected to grow more slowly and have delayed maturity (Atkinson 1994; Berrigan and Charnov 1994). This is not the case for all species; some populations are able to compensate for shorter growing seasons and have similar or higher reproductive rates compared to southern conspecifics (Tuttle and Gregory 2012, 2014).

The ability of a female to successfully reproduce in any given year is typically dependent on body condition. Most northern reptiles are viviparous with lecithotrophic embryos requiring provisioning predevelopment. The time required to replenish energy stores may delay subsequent reproduction and lead to less than annual reproduction. In some species, yolk is supplemented by limited placental nourishment, allowing gravid snakes some control of provisioning during development (King 1993). In these cases, prolonged gestation would allow for larger or more neonates. This has a cost, as prolonged gestation limits the ability of the mother to feed that, in an already short season, may lead to tradeoffs in energy expenditure not required in less stressful environments.

In high-latitude regions many snakes are not always able to maintain ideal body temperatures, even during the active season (Blouin-Demers and Weatherhead 2001). Reproductive requirements of females also contribute to differences in habitat use and temperature selection between sexes. Thermal requirements to grow 
developing embryos may cause females to select different habitats than males and alter their thermoregulatory behaviour (Shine et al. 2006). The cold-climate hypothesis predicts that warmer temperatures will be selected by gravid female squamates in cold climates to ensure rapid embryo development (Tinkle and Gibbons 1977). This may lead to increased use of more thermally attractive open or edge habitat than in other parts of a species' range.

Cold-climate reptiles can avoid inclement conditions and limit energy expenditures through hibernation (Gregory 2009). Failure to select appropriate hibernacula leads to death but selecting purely for overwinter survival also has associated costs (Gienger and Beck 2011). Time spent in hibernation subtracts from time spent foraging, therefore hibernacula are often chosen to extend the length of the active season (Gienger and Beck 2011). Features often associated with successful hibernation sites allow for access to soil below the frost line, stability in humidity and temperature, and access to the water table (Harvey and Weatherhead 2006a). The availability of suitable hibernacula is likely the most important form of habitat selection for snakes at high latitudes and may limit the distribution of some species (Harvey and Weatherhead 2006b).

Red-bellied Snake (Storeria occipitomaculata) occupies most of eastern North America and is widely distributed in Canada, reaching the northwestern edge of its range in eastern Saskatchewan (Ernst and Ernst 2003). Across its range there have been a number of studies of this species (e.g., Blanchard 1937; Lang 1969; Semlitsch and Moran 1984; Willson and Dorcas 2004; Brown and Phillips 2012) but there has been little research at its northern range limit, with the exception of two natural history observations (Criddle 1937; Gregory 1977). Storeria occipitomaculata is a small-bodied, cryptic snake that comes in several ground-shaded dorsal colour morphs and has a bright, reddish-orange ventral surface. They are viviparous, likely with some limited placental provisioning (Blackburn et al. 2009). This species, like other members of the genus Storeria, feeds primarily on molluscs (Trapido 1944; Brown 1979; Semlitsch and Moran 1984; Pisani and Busby 2011) although not exclusively (Ernst and Ernst 2003). With few species of slugs and snails native to the northwestern edge of its range, local diet remains unknown. This species is considered uncommon to rare throughout much of its range (Ernst and Ernst 2003) but it can be abundant in suitable habitat (Lang 1971). Little is known about population densities for this species, although most studies have recorded low recapture rates (Blanchard 1937; Gregory 1977; Semlitsch and Moran 1984). Typically, S. occipitomaculata inhabit thick grassy, herbaceous, and shrubby vegetation, and also can be found in wetlands, riparian areas, and along forest edges and in old field and prairie habitats (Wright and Wright 1957; Cook 1984; Pisani and Busby 2011) as well as drier grasslands habitats (Lang 1969; Brown and Phil- lips 2012). Criddle (1937) and Lang (1969) both found this species to use abandoned (or nearly so) ant mounds of species of the genus Formica as overwintering sites, with the snakes often found hibernating at high densities.

The objective of this study is to examine demography, morphology, reproduction, habitat use, and hibernation in populations of $S$. occipitomaculata near their northern range limit. The stressful environment at high latitudes may force these populations to make trade-offs in their growth, reproduction, and habitat use. We asked the following questions: 1) What are the demographics, morphology, and reproductive traits of this population of S. occipitomaculata? and 2) Under what conditions do they hibernate?

\section{Methods}

Study sites

Field work in summer habitat use took place in southwestern Manitoba, Canada at the following locations (Figure 1a): Spruce Woods Provincial Park (SWPP; $49.7108^{\circ} \mathrm{N}, 99.2528^{\circ} \mathrm{W}$ ), Assiniboine Corridor Wildlife Management Area (ACWMA; $\left.49.6675^{\circ} \mathrm{N}, 99.5614^{\circ} \mathrm{W}\right)$, Oak Lake $\left(49.6644^{\circ} \mathrm{N}, 100.7133^{\circ} \mathrm{W}\right)$, and Canadian Forces Base Shilo (CFB Shilo; $49.7381^{\circ} \mathrm{N}, 99.5183^{\circ} \mathrm{W}$ ). A wide variety of habitats were investigated, including agricultural areas, beaver ponds, mixed forest, and mixed-grass prairie. Most sites included water and/or mixed grass prairie. Investigation into hibernation was conducted at the Souris River Bend Wildlife Management Area (SRBWMA; $49.4883^{\circ} \mathrm{N}, 99.8775^{\circ} \mathrm{W}$; Figure 1b). Habitat at this area includes mixed forest and grassland, bordered by marsh, agricultural fields, and gravel roads. Details on the habitat types are provided below.

\section{Demography and morphometrics}

We recorded the following measurements for all snakes: date, time, snout-vent length (SVL in $\mathrm{mm}$ ), tail length $(\mathrm{mm})$, head width $(\mathrm{mm})$, head length $(\mathrm{mm})$, mass (g), sex, age, and reproductive condition. We classified all individuals into three age classes: young-of-year (YOY), juvenile, and adult. Storeria occipitomaculata were classified into age classes based on their SVL, natal scars, and the minimum breeding SVL of females: YOY $(<110 \mathrm{~mm})$, juvenile $(100-154 \mathrm{~mm})$, and adult $(>154 \mathrm{~mm})$. For the age-class analysis we only included the first capture for individuals that were recaptured multiple times within the same season.

To determine reproductive condition, two researchers independently counted enlarged ovarian follicles by palpation (Fitch 1987) and the average of their counts was recorded. All captured individuals were scaleclipped for identification and released at their capture site within 15 minutes of capture. The activity period (27 April to 8 September) was classified by two-week periods numbered 1 through 10 . No snakes in this study received more than three clipped ventral scales. 

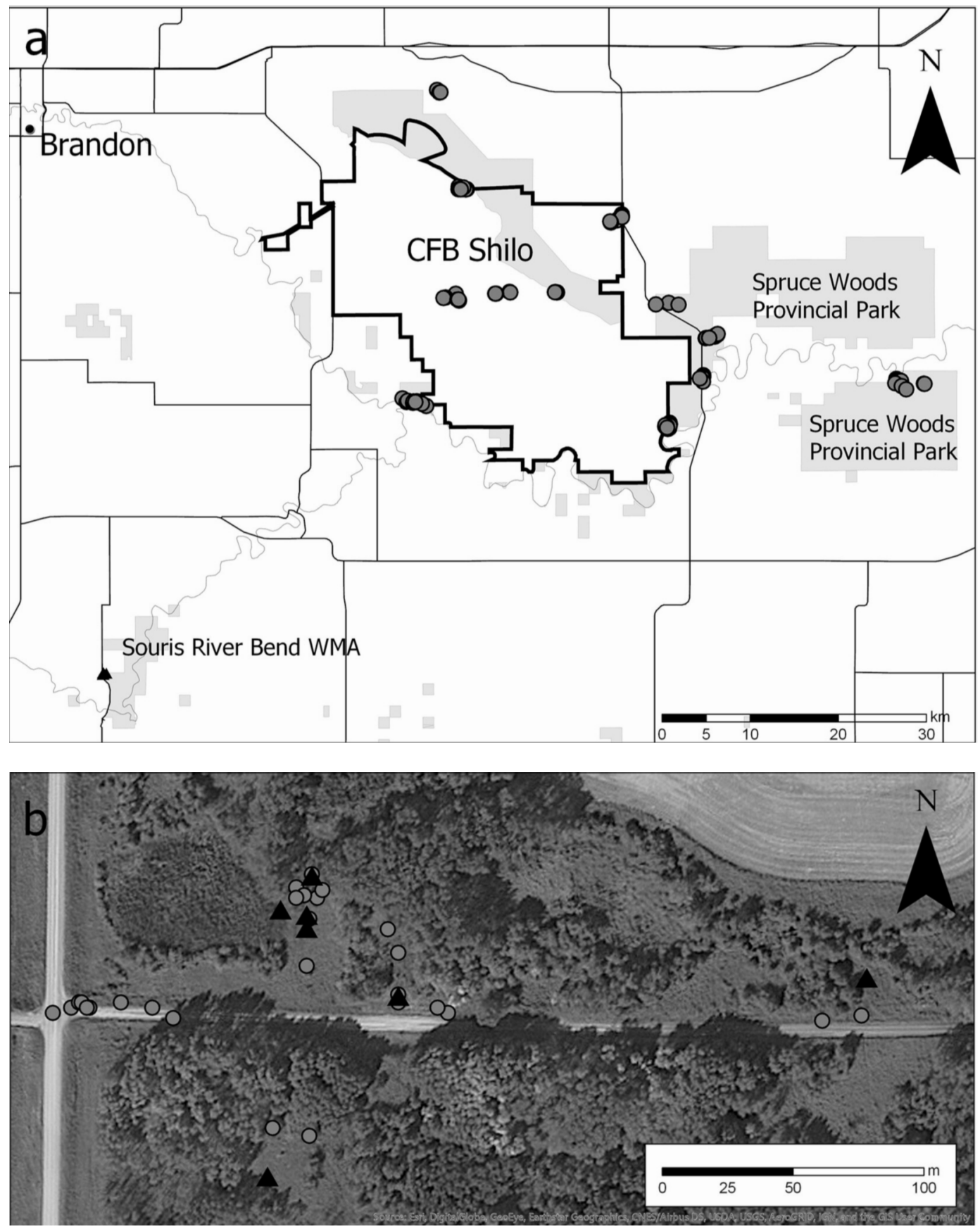

FigUre 1. a. Map of summer sites (grey circle) and hibernation sites (black triangle) surveyed for Red-bellied Snake (Storeria occipitomaculata) 2007-2010 in southwestern Manitoba. b. Map of hibernation study site at Souris River Bend Wildlife Management Area surveyed 2007-2010 showing den sites (black triangle) where traps were set and locations of individual captures (grey circle) outside of the traps. Base map from World Imagery. Accessed 7 October 2018. https://support.esri.com/en/tech nical-article/000012040. 


\section{Summer activity}

Field sites were surveyed every $2-3$ weeks in $2007-$ 2009, from April to September of each year. Surveys were done at various times of day to compare daily habitat usage as the season progressed. We used the same search corridor each time a site was visited to standardize search effort. These routes travelled around or through potentially suitable habitat, often following barriers such as creeks, park paths, or tree lines. Animals were captured by hand as they moved in the open, or when located under cover objects, both natural and artificial (e.g., plywood, sheet metal).

We recorded the following environmental and location data at each capture site: universal transverse mercator coordinates, capture location (in the open or under cover, cover type, and cover thickness), and aspect $\left(0-360^{\circ}\right)$. Collection localities were recorded using a Garmin ${ }^{\circledR}$ GPS60 handheld global positioning system (GPS) receiver (Olathe, Kansas, USA; WAAS enabled accuracy: $<3 \mathrm{~m}, 95 \%$ typical). GPS data were used to classify the capture locations according to land cover classes defined by the Manitoba Land Initiative (2012). The following seven classes were used: agriculture, bogs, coniferous forest, deciduous forest, mixedwood forest, grassland, and roads (including trails). Assignments were made using ArcGIS version 10 (ESRI 2011).

\section{Hibernation field data collection}

This study took place from September 2007 to June 2010, targetting spring and fall (from 12 April to 5 June in 2008; from 6 May to 2 June in 2009; from 4 April to 20 May in 2010; from 15 September to 4 October in 2007; from 6 September to 25 October in 2008, and 20 September to 4 October in 2009). No traps were used in 2009 (see below for a further description of trapping).

Five abandoned ant mounds were monitored throughout the study (Figure 1b). We replaced two of the mounds that were monitored in 2007 and 2008 with two new mounds in 2008, 2009, and 2010 because the mounds monitored in 2007 and 2008 were destroyed. All ant mounds were ringed with $40 \mathrm{~cm}$ tall aluminum flashing. Three openings were cut in the aluminum flashing and a mesh funnel trap made of hardware cloth was placed in each. In fall, two traps were placed on the inside of the flashing at every mound to capture individuals entering the mounds, and one trap was placed on the outside to capture individuals exiting the mounds; the reverse occurred in the spring trapping sessions. Traps were checked every $24-48 \mathrm{~h}$ and all individuals were removed from traps. Visual searches were also conducted around the trap sites when traps were checked. All captured individuals were measured (as described above), given a unique scale-clip, and released at the capture site. Individuals caught in traps were released in their direction of travel.

Temperature profiles of the ant mounds were created using iButton ${ }^{\circledR}$ thermal probes (San Jose, California, USA) attached to plastic landscaping rods. iButtons ${ }^{\circledR}$ were placed in Ziploc ${ }^{\circledR}$ bags and attached to the poles using duct tape. They were deployed over two winters, from 27 September 2007 to 29 May 2008 and 20 September 2008 to 3 June 2009 . The iButtons ${ }^{\circledR}$ were set at four distances from the surface: $40,80,120,160 \mathrm{~cm}$ in the 2007-2008 hibernation period; and at $0,40,80$, $120 \mathrm{~cm}$ in the 2008-2009 hibernation period. Temperatures were recorded every $3 \mathrm{~h}$. In 2007-2008 all iButtons ${ }^{\circledR}$ deployed at $160 \mathrm{~cm}$ below the surface failed because they were below the water table. We did not deploy any iButtons ${ }^{\circledR}$ at this depth in 2008-2009. In 2008-2009, air temperature (1.5 $\mathrm{m}$ above the surface) was also recorded.

\section{Statistical analysis}

All data analyses were done in R 3.2.1 (R Development Core Team 2017) with $\alpha=0.05$. We report means, $\mathrm{SE}$, and ranges. Data were log-transformed or nonparametric tests were used, when assumptions of parametric tests were not satisfied. Unless otherwise indicated, adult females include both gravid and non-gravid individuals. Unpaired $t$-tests (package stats; function t.test) were used to compare SVLs within and between sexes, and those captured in the summer versus at the hibernation site (spring and fall). Chi-square analyses (package stats; function chisq.test) were used to compare among categorical variables (see Table 1 for all comparisons). Linear models (package stats; function $\mathrm{lm}$ ) were used to test for morphological and reproductive relationships (see Table 2 for detailed models). For $P$ values between 0.05 and 0.1 power analyses were conducted (package pwr) with reference power $=0.80$.

We calculated the mean temperature at each depth for all five dens for each $3 \mathrm{~h}$ period within each year. In some cases, we did not have temperatures for all depths at all den sites due to failure of some of the iButtons ${ }^{\circledR}$. In 2007-2008, one iButton $®$ failed at a den site at both the $80 \mathrm{~cm}$ and $120 \mathrm{~cm}$ depths. In 2008-2009, one iButton ${ }^{\circledR}$ failed at the $80 \mathrm{~cm}$ depth, and three iButtons ${ }^{\circledR}$ failed at the $120 \mathrm{~cm}$ depth. Air temperature and surface temperature $(0 \mathrm{~cm})$ were only recorded in 2008-2009.

\section{Results}

Summer demography, morphometrics, and habitat use

Over the three years we captured 88 individuals (Table S1). Most individuals were adults $(n=81 ; 92 \%)$, with only five juveniles and two YOY captured. There was no significant difference in the numbers of captures in each age class (YOY, juvenile, adult) among the three years (Table 1) and no significant difference in the numbers of adult males and females captured among years (Table 1). Adult sex ratios varied during the active season (Table 1; Figure 2) with more males captured in late summer (after 3 August).

Adult female $S$. occipitomaculata tended to be longer (female: $184.2 \pm 2.2 \mathrm{~mm}$; male: $175.3 \pm 4.0$; male: female body size $\left.=0.95 ; t_{31.3}=1.94, P=0.06\right)$. Samples were unequal (female: $n=53$; male: $n=21$ ) and power was low (0.50; package pwr; function pwr.t2n.test). 
TABLE 1. Chi-square test statistics for comparisons among categories for: summer sites and hibernation sites for Red-bellied Snake (Storeria occipitomaculata).

\begin{tabular}{|c|c|c|c|c|}
\hline$\overline{\text { Category }}$ & Comparison & $\chi^{2}$ & $d f$ & 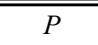 \\
\hline $\begin{array}{l}\text { SUMMER } \\
\text { age class (YOY, J, AD)* } \\
\text { adult sex } \\
\text { adult sex } \\
\text { activity (10 periods) } \\
\text { adult sex }\end{array}$ & $\begin{array}{l}\text { year } \\
\text { year } \\
\text { activity (10 periods) } \\
\text { land-cover use } \\
\text { land-cover use }\end{array}$ & $\begin{array}{r}4.04 \\
4.02 \\
18.44 \\
62.35 \\
1.34\end{array}$ & $\begin{array}{r}4 \\
2 \\
9 \\
27 \\
3\end{array}$ & $\begin{array}{r}0.400 \\
0.130 \\
0.030 \\
<0.001 \\
0.720\end{array}$ \\
\hline $\begin{array}{l}\text { HIBERNATION } \\
\text { age class (YOY, J, AD)* } \\
\text { adult sex } \\
\text { species }\end{array}$ & $\begin{array}{l}\text { spring versus fall } \\
\text { spring versus fall } \\
\text { capture location (trap, mound, } \\
\text { road, and grassland) }\end{array}$ & $\begin{array}{r}86.28 \\
0.17 \\
28.33\end{array}$ & $\begin{array}{l}2 \\
1\end{array}$ & $\begin{array}{r}<0.001 \\
0.680 \\
<0.001\end{array}$ \\
\hline $\begin{array}{l}\text { direction of movement (entering } \\
\text { versus exiting) }\end{array}$ & spring versus fall & 0.40 & 1 & 0.530 \\
\hline
\end{tabular}

*YOY = young-of-year; $\mathrm{J}=$ juvenile; $\mathrm{AD}=$ adult.

TABLE 2. Linear models to test for the effects of snout-vent length (SVL) and sex of Red-bellied Snake (Storeria occipitomaculata) on tail length, head width, head length, natural log-transformed mass, and number of follicles. Models were done separately for summer sites $(\mathrm{S})$ and the hibernation site $(\mathrm{H})$. The final linear model tests for the effect of year and SVL on the number of follicles in adult females captured at summer sites.

\begin{tabular}{|c|c|c|c|c|c|c|}
\hline \multicolumn{2}{|l|}{$\overline{\text { Model }}$} & \multirow{2}{*}{$\begin{array}{c}\text { Site type } \\
\mathrm{S}\end{array}$} & \multirow{2}{*}{$\begin{array}{c}F \\
3.95\end{array}$} & \multirow{2}{*}{$\begin{array}{c}d f \\
3,69\end{array}$} & \multirow{2}{*}{$\begin{array}{c}P \\
0.010\end{array}$} & \multirow{2}{*}{$\begin{array}{c}\text { Adjusted } r^{2} \\
0.11\end{array}$} \\
\hline tail length $=$ & $\operatorname{sex}+\mathrm{SVL}+\operatorname{sex} \times \mathrm{SVL}$ & & & & & \\
\hline & & $\mathrm{H}$ & 51.34 & 3,39 & $<0.001$ & 0.78 \\
\hline & sex & $\mathrm{S}$ & 6.83 & 1,69 & 0.010 & \\
\hline & & $\mathrm{H}$ & 38.54 & 1,39 & $<0.001$ & \\
\hline & SVL & $\mathrm{S}$ & 3.76 & 1,69 & 0.060 & \\
\hline & & $\mathrm{H}$ & 115.28 & 1,39 & $<0.001$ & \\
\hline & $\operatorname{sex} \times \mathrm{SVL}$ & $\mathrm{S}$ & 1.26 & 1,69 & 0.260 & \\
\hline & & $\mathrm{H}$ & 0.20 & 1,39 & 0.660 & \\
\hline \multirow[t]{8}{*}{ head width $=$} & $\operatorname{sex}+\mathrm{SVL}+\operatorname{sex} \times \mathrm{SVL}$ & $\mathrm{S}$ & 4.25 & 3,69 & 0.008 & 0.12 \\
\hline & & $\mathrm{H}$ & 16.18 & 3,39 & $<0.001$ & 0.52 \\
\hline & sex & $\mathrm{S}$ & 3.19 & 1,69 & 0.080 & \\
\hline & & $\mathrm{H}$ & 1.16 & 1,39 & 0.290 & \\
\hline & SVL & $\mathrm{S}$ & 8.29 & 1,69 & 0.005 & \\
\hline & & $\mathrm{H}$ & 47.35 & 1,39 & $<0.001$ & \\
\hline & sex $\times$ SVL & $\mathrm{S}$ & 1.28 & 1,69 & 0.260 & \\
\hline & & $\mathrm{H}$ & 0.01 & 1,39 & 0.910 & \\
\hline \multirow[t]{8}{*}{ head length $=$} & $\operatorname{sex}+\mathrm{SVL}+\operatorname{sex} \times \mathrm{SVL}$ & $\mathrm{S}$ & 9.18 & 3,62 & $<0.001$ & 0.27 \\
\hline & & $\mathrm{H}$ & 16.43 & 3,26 & $<0.001$ & 0.61 \\
\hline & $\operatorname{sex}$ & $\mathrm{S}$ & 3.02 & 1,62 & 0.090 & \\
\hline & & $\mathrm{H}$ & 1.15 & 1,26 & 0.290 & \\
\hline & SVL & $\mathrm{S}$ & 23.30 & 1,62 & $<0.001$ & \\
\hline & & $\mathrm{H}$ & 43.95 & 1,26 & $<0.001$ & \\
\hline & sex $\times$ SVL & $\mathrm{S}$ & 1.21 & 1,62 & 0.270 & \\
\hline & & $\mathrm{H}$ & 4.19 & 1,26 & 0.050 & \\
\hline \multirow[t]{8}{*}{$\log ($ mass $)=$} & $\operatorname{sex}+\mathrm{SVL}+\operatorname{sex} \times \mathrm{SVL}$ & $\mathrm{S}$ & 60.12 & 3,69 & $<0.001$ & 0.71 \\
\hline & & $\mathrm{H}$ & 119.20 & 3,39 & $<0.001$ & 0.89 \\
\hline & $\operatorname{sex}$ & $\mathrm{S}$ & 39.76 & 1,69 & $<0.001$ & \\
\hline & & $\mathrm{H}$ & 2.25 & 1,39 & 0.140 & \\
\hline & SVL & $\mathrm{S}$ & 140.16 & 1,69 & $<0.001$ & \\
\hline & & $\mathrm{H}$ & 350.32 & 1,39 & $<0.001$ & \\
\hline & sex $\times$ SVL & $\mathrm{S}$ & 0.45 & 1,69 & 0.500 & \\
\hline & & $\mathrm{H}$ & 5.15 & 1,39 & 0.030 & \\
\hline \multirow[t]{4}{*}{ no. follicles $=$} & year $+\mathrm{SVL}+$ year $\times \mathrm{SVL}$ & $\mathrm{S}$ & 9.53 & 5,68 & $<0.001$ & 0.38 \\
\hline & year & $\mathrm{S}$ & 11.80 & 2,33 & $<0.001$ & \\
\hline & SVL & $\mathrm{S}$ & 22.61 & 1,33 & 0.040 & \\
\hline & year $\times$ SVL & $\mathrm{S}$ & 0.12 & 2,33 & 0.890 & \\
\hline
\end{tabular}




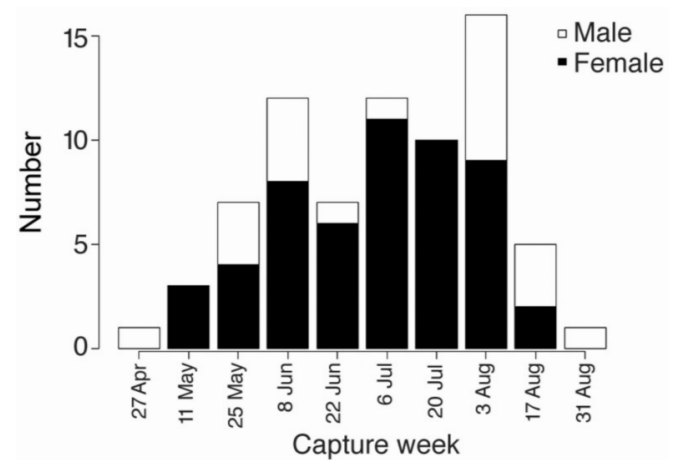

Figure 2. Numbers of adult male and female Red-bellied Snake (Storeria occipitomaculata) captured during summer surveys 2007-2009 at Spruce Woods Provincial Park (SWPP), Assiniboine Corridor Wildlife Management Area (ACWMA), Oak Lake, and Canadian Forces Base Shilo (CFB Shilo). The season was divided into ten, two-week periods and the capture week indicates the start of the two-week period.
Sample sizes of 60 in each group would have detected a significant difference $(a<0.05)$ with power $=0.80$. Males had significantly longer tails than females (Table 2; Figure 3a). Males tended to have wider and longer heads (Table 2). Females were significantly heavier than males (Table 2; Figure 3b).

The majority of adult females captured were gravid $(n=46 ; 96 \%)$. Enlarged follicles were detected from 14 May to 11 August. Gravid females had 4-12 follicles (modes $=5,6,7$, and 10, median $=7$ ). The number of follicles increased with SVL (Table 2; Figure 4) and was significantly different among the three years (2007: modes $=0,4$, and 7 , median $=6 ; 2008$ : mode $=6$, median $=6 ; 2009$ : mode $=10$, median $=9$; Table 2; Figure 4).

Individuals were most commonly found in grassland habitat $(n=51 ; 59 \%)$, followed by deciduous forest $(n$ $=22 ; 25 \%)$, roads $(n=9 ; 10 \%)$, and mixedwood forest $(n=5 ; 6 \%)$. Land-cover use differed across the 10, two week periods (Table 1; Figure 5). Mixedwood forest
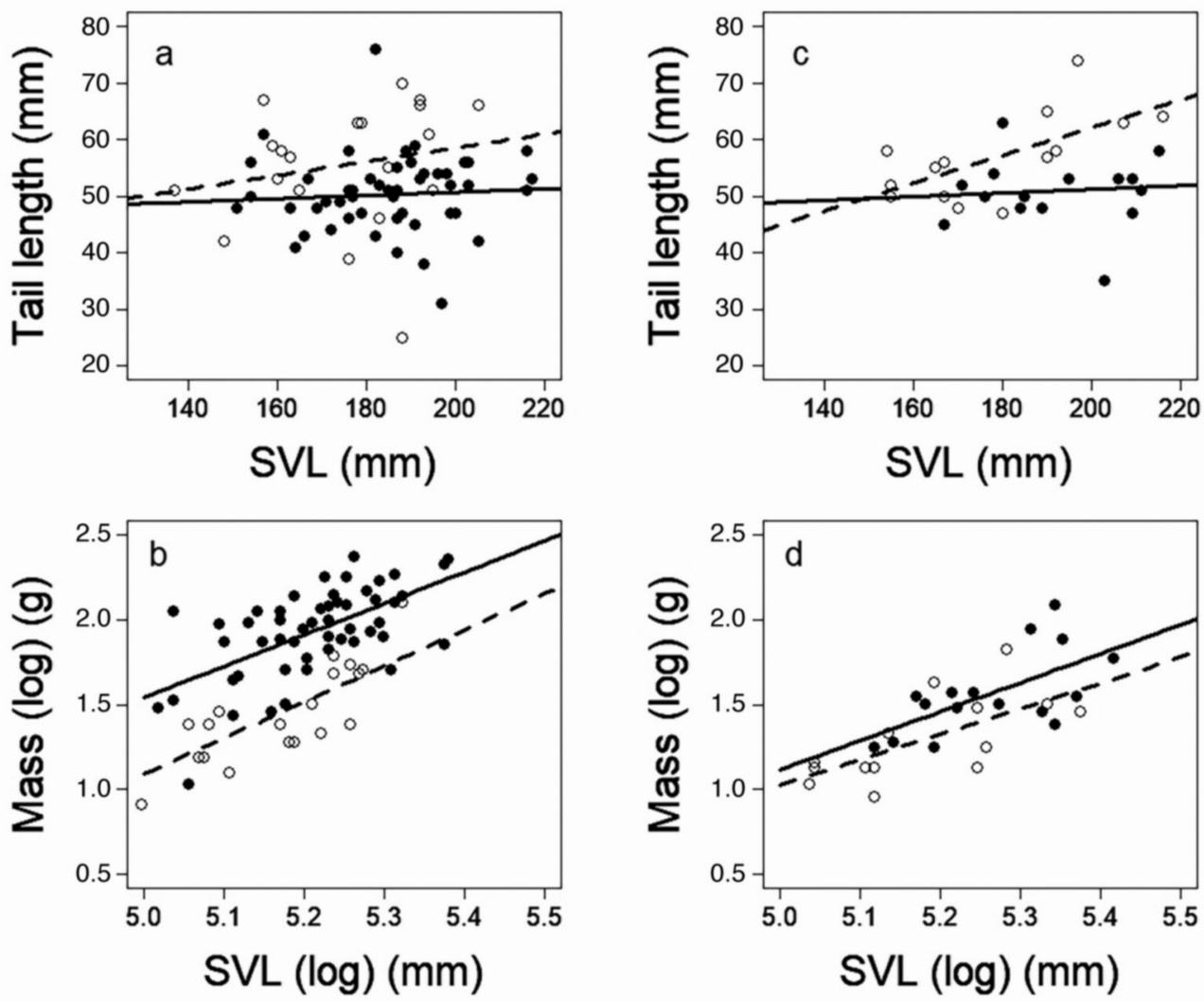

Figure 3. a. Snout-vent length (SVL) versus tail length, and b. natural log-transformed SVL versus natural log-transformed mass for adult male (open circle, dashed line) and female (filled circle, solid line) Red-bellied Snake (Storeria occipitomaculata) captured during summer surveys 2007-2009 at Spruce Woods Provincial Park (SWPP), Assiniboine Corridor Wildlife Management Area (ACWMA), Oak Lake, and Canadian Forces Base Shilo (CFB Shilo). c. SVL versus tail length, and d. natural log-transformed SVL versus natural log-transformed mass for adult male (open circle, dashed line) and female (filled circle, solid line) S. occipitomaculata captured during spring and fall surveys 2007-2010 at the hibernation site (Souris River Bend Wildlife Management Area). 


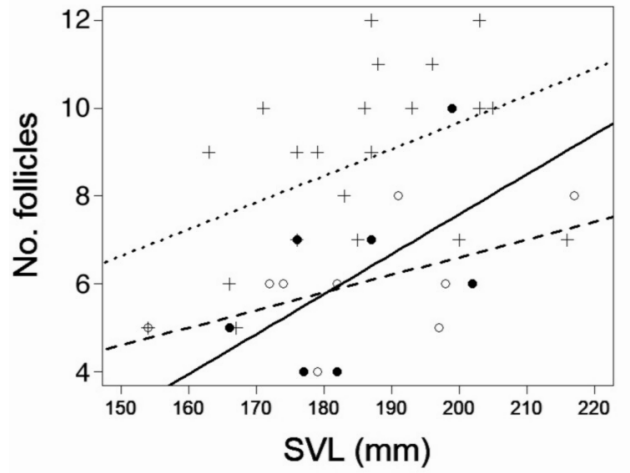

FigUre 4. Snout-vent length (SVL) versus number of follicles for adult gravid female Red-bellied Snake (Storeria occipitomaculata) captured during summer surveys 2007-2009 at Spruce Woods Provincial Park (SWPP), Assiniboine Corridor Wildlife Management Area (ACWMA), Oak Lake, and Canadian Forces Base Shilo (CFB Shilo). Linear regressions are shown separately for each year: 2007 (open circle, dashed line), 2008 (filled circle, solid line), and 2009 (cross, dotted line).

was used in spring (11 May to 15 June), while roads and grassland were most commonly used in late summer (3-10 August). There was no difference in landcover use of males and females (Table 1).

Approximately a third of captures were on flat ground $(n=23 ; 30 \%)$. Individuals that were captured on slopes were captured on slopes with a mean aspect of $18.2 \pm$ $1.04^{\circ}$ (south facing). Most captures were under cover $(n=73 ; 87 \%)$. Preferred cover types were: plywood $(n=41 ; 56 \%)$, natural $\log (n=9 ; 12 \%)$, railway tie $(n=$ $8 ; 11 \%)$, plank $(n=6 ; 8 \%)$, and other $(n=9 ; 13 \%)$. Mean cover thickness was $36.5 \pm 5.2 \mathrm{~mm}$ (range $=1-$ $220 \mathrm{~mm}$, median $=19 \mathrm{~mm}$ ). Sampling effort for slope and cover types was not quantified. Therefore, the above values do not necessarily reflect habitat selection, and may simply reflect a bias in availability.

Hibernation demography, morphometrics, and habitat use

At the hibernation site (SRBWMA) we found 57 individuals representing all three age classes for $S$. occipitomaculata. Adults were the most common ( $n$ $=35 ; 61 \%)$, followed by similar percentages of juveniles $(n=12 ; 21 \%)$ and YOY $(n=10 ; 18 \%)$. There was a significant difference in the numbers caught by age class (YOY, juvenile, adult) between spring and fall (Table 1). In the fall there were more adults $(n=25$; $71 \%$ of all adults $)$ and YOY $(n=10 ; 100 \%$ of all YOY $)$ captured, and more juveniles captured in the spring ( $n$ $=11 ; 89 \%$ of all juveniles). There was no significant difference in the numbers of males and females captured in the spring versus the fall (Table 1). Adult female $S$. occipitomaculata captured at the hibernation site were significantly larger than males $(193.9 \pm 4.4$ $\mathrm{mm}$ and $178.9 \pm 5.4 \mathrm{~mm}$ respectively; $t_{26.1}=2.17, P=$ $0.04)$. Males had significantly longer tails than females

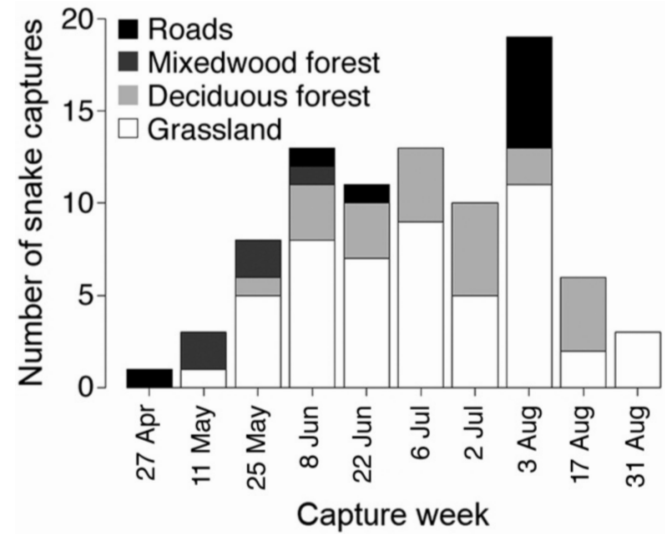

Figure 5. Habitat use of Red-bellied Snake (Storeria occipitomaculata) captured during summer surveys 2007-2009 at Spruce Woods Provincial Park (SWPP), Assiniboine Corridor Wildlife Management Area (ACWMA), Oak Lake, and Canadian Forces Base Shilo (CFB Shilo). The season was divided into ten two-week periods and the capture week indicates the start of the two-week period.

(Table 2; Figure 3c). There was no difference between head widths (Table 2) or head lengths of males and females (Table 2). There was no difference in mass between males and females (Table 2; Figure 3d).

Storeria occipitomaculata shared the hibernation site with three other species of snakes: Plains Garter Snake (Thamnophis radix), Red-sided Garter Snake (T. sirtalis parietalis), and Smooth Greensnake (Opheodrys vernalis) that used both the surrounding area and den sites. Over three years we captured 166 individuals (Table 3). Most were found during fall surveys $(n=$ $114 ; 69 \%)$. Trapping percentages were highest in $O$. vernalis and T. radix (Table 4). Individuals were first captured in traps on 16 September 2007, 13 September 2008, and 23 September 2009. Timing of the first spring captures in traps was more variable: 7 May 2009 and 9 April 2010. More individuals were captured during our visual searches, either in the grassland $(n=50$; $30 \%)$, on the road $(n=28 ; 17 \%)$, or inside aluminum flashing on ant mounds $(n=13 ; 8 \%)$. The remaining individuals $(n=75 ; 45 \%)$ were captured inside traps. There were significant differences among the four species in capture sites (Table 1). Storeria occipitomaculata and $O$. vernalis were captured significantly more often on roads than Thamnophis spp. Most snakes found in the grassland were $T$. sirtalis parietalis, and there were no $O$. vernalis found in this habitat. Most snakes found on ant mounds were Thamnophis spp.

There was no significant difference in direction of movement (entering or exiting the ant mound) in fall as compared to spring (Table 1). Few $S$. occipitomaculata, $T$. radix, and $T$. sirtalis parietalis were recaptured within the same season ( $11 \%$ in total; Table S2). There were only three individuals ( $2 \%$; all Thamnophis spp.) recaptured between seasons; one of these individuals had 
TABLE 3. Numbers of each species captured in different capture locations (trap, ant mound, road, or grassland) at the Souris River Bend Wildlife Management Area study site 2007-2010. Percentages within each category are indicated in brackets. Species are: Smooth Greensnake (Opheodrys vernalis), Northern Red-bellied Snake (Storeria occipitomaculata), Plains Garter Snake (Thamnophis radix), and Red-sided Garter Snake (Thamnophis sirtalis parietalis). Only visual searches were conducted in fall 2009.

\begin{tabular}{|c|c|c|c|c|c|c|}
\hline $\begin{array}{l}\text { Year, } \\
\text { season }\end{array}$ & $\begin{array}{l}\text { Capture } \\
\text { location }\end{array}$ & $\begin{array}{c}\text { Smooth } \\
\text { Greensnake }\end{array}$ & $\begin{array}{c}\text { Northern } \\
\text { Red-bellied Snake }\end{array}$ & $\begin{array}{c}\text { Plains } \\
\text { Garter Snake }\end{array}$ & $\begin{array}{c}\text { Red-sided } \\
\text { Garter Snake }\end{array}$ & Total \\
\hline 2007, fall & $\begin{array}{l}\text { Trap } \\
\text { Mound } \\
\text { Road } \\
\text { Grassland } \\
\text { Total }\end{array}$ & $\begin{array}{l}0 \\
0 \\
1 \\
0 \\
1\end{array}$ & $\begin{array}{r}16 \\
0 \\
1 \\
1 \\
18\end{array}$ & $\begin{array}{l}4 \\
1 \\
0 \\
1 \\
6\end{array}$ & $\begin{array}{l}2 \\
4 \\
0 \\
0 \\
6\end{array}$ & $\begin{array}{r}22(71) \\
5(16) \\
2(6) \\
2(6) \\
31\end{array}$ \\
\hline 2008, spring & $\begin{array}{l}\text { Trap } \\
\text { Mound } \\
\text { Road } \\
\text { Grassland } \\
\text { Total }\end{array}$ & $\begin{array}{l}1 \\
0 \\
0 \\
0 \\
1\end{array}$ & $\begin{array}{l}0 \\
0 \\
0 \\
0 \\
0\end{array}$ & $\begin{array}{l}1 \\
0 \\
0 \\
1 \\
2\end{array}$ & $\begin{array}{l}0 \\
0 \\
0 \\
1 \\
1\end{array}$ & $\begin{array}{r}2(50) \\
0 \\
0 \\
2(50) \\
4\end{array}$ \\
\hline 2008 , fall & $\begin{array}{l}\text { Trap } \\
\text { Mound } \\
\text { Road } \\
\text { Grassland } \\
\text { Total }\end{array}$ & $\begin{array}{l}4 \\
1 \\
1 \\
0 \\
6\end{array}$ & $\begin{array}{r}4 \\
1 \\
16 \\
1 \\
22\end{array}$ & $\begin{array}{l}5 \\
0 \\
1 \\
1 \\
7\end{array}$ & $\begin{array}{r}24 \\
5 \\
3 \\
12 \\
44\end{array}$ & $\begin{array}{r}37(46) \\
7(9) \\
21(27) \\
14(18) \\
79\end{array}$ \\
\hline 2009 , spring & $\begin{array}{l}\text { Trap } \\
\text { Mound } \\
\text { Road } \\
\text { Grassland } \\
\text { Total }\end{array}$ & $\begin{array}{l}0 \\
0 \\
0 \\
0 \\
0\end{array}$ & $\begin{array}{l}3 \\
0 \\
2 \\
4 \\
9\end{array}$ & $\begin{array}{l}0 \\
0 \\
1 \\
1 \\
2\end{array}$ & $\begin{array}{r}0 \\
0 \\
0 \\
13 \\
13\end{array}$ & $\begin{array}{r}3(13) \\
0 \\
3(13) \\
18(75) \\
24\end{array}$ \\
\hline 2009 , fall & $\begin{array}{l}\text { Road } \\
\text { Grassland } \\
\text { Total }\end{array}$ & $\begin{array}{l}1 \\
0 \\
1\end{array}$ & $\begin{array}{l}1 \\
2 \\
3\end{array}$ & $\begin{array}{l}0 \\
0 \\
0\end{array}$ & $\begin{array}{l}0 \\
0 \\
0\end{array}$ & $\begin{array}{r}2(50) \\
2(50) \\
4\end{array}$ \\
\hline 2010 , spring & $\begin{array}{l}\text { Trap } \\
\text { Mound } \\
\text { Road } \\
\text { Grassland } \\
\text { Total }\end{array}$ & $\begin{array}{l}2 \\
0 \\
0 \\
0 \\
2\end{array}$ & $\begin{array}{r}4 \\
0 \\
0 \\
8 \\
12\end{array}$ & $\begin{array}{l}2 \\
1 \\
0 \\
1 \\
4\end{array}$ & $\begin{array}{l}3 \\
0 \\
0 \\
3 \\
6\end{array}$ & $\begin{array}{r}11(46) \\
1(4) \\
0 \\
12(50) \\
24\end{array}$ \\
\hline Total & $\begin{array}{l}\text { Trap } \\
\text { Mound } \\
\text { Road } \\
\text { Grassland } \\
\text { Total }\end{array}$ & $\begin{array}{r}7(64) \\
1(9) \\
3(27) \\
0 \\
11(7)\end{array}$ & $\begin{array}{r}27(42) \\
1(2) \\
20(31) \\
16(25) \\
64(39)\end{array}$ & $\begin{array}{r}12(57) \\
2(10) \\
2(10) \\
5(24) \\
21(13)\end{array}$ & $\begin{array}{r}29(41) \\
9(13) \\
3(4) \\
29(41) \\
70(42)\end{array}$ & $\begin{array}{r}75(45) \\
13(8) \\
28(17) \\
50(30) \\
166\end{array}$ \\
\hline
\end{tabular}

also been recaptured within a season. No $O$. vernalis were recaptured. Few individuals were found dead on the road $(3 \%)$ or dead in a trap or within the aluminum flashing $(3 \%)$. When individuals were recaptured within the season, they were most frequently first captured in a trap entering the ant mound and secondly captured in a trap exiting the ant mound $(n=11 ; 61 \%)$. All other recaptures (first capture/second capture) were grassland/ road (T. sirtalis parietalis; $n=2$ ), grassland/grassland (T. sirtalis parietalis; $n=2$ ), road/road (S. occipitomaculata; $n=1$ ), mound/grassland (T. sirtalis parietalis; $n=1$ ), and mound/mound ( $T$. sirtalis parietalis, $n=1$ ). A single T. sirtalis parietalis was recaptured, both times in a trap that exited the mound.

\section{Thermal profiles of den sites}

Air temperature and surface temperature $(0 \mathrm{~cm})$ were highly variable, and both stayed below freezing from 1 November to 1 March (Figure 6). Temperatures at a depth of $40 \mathrm{~cm}$ were more stable but were below freez- ing from 1 December to 1 April. Temperatures at a depth of $80 \mathrm{~cm}$ and $120 \mathrm{~cm}$ below the surface were also stable but largely stayed above freezing. In 2007-2008, the temperature at the $80 \mathrm{~cm}$ depth dipped to minus $0.1^{\circ} \mathrm{C}$ in February but stayed above freezing in 20082009.

\section{Summer versus hibernation morphometrics}

Adult females tended to be larger at the hibernation site than at summer sites (hibernation: $193.9 \pm 4.4 \mathrm{~mm}$; summer: $\left.184.2 \pm 2.2 \mathrm{~mm} ; t_{23.3}=1.99, P=0.06\right)$. Sample sizes were unequal (summer: $n=53$; hibernation: $n=17)$, and power was low (0.54; package pwr; function pwr.t2n.test). Sample sizes of 47 in each group would have detected a significant difference $(a<0.05)$ with power $=0.80$. There was no significant difference in SVL of adult males captured at the hibernation site compared to the summer sites (hibernation: $178.9 \pm$ $5.4 \mathrm{~mm}$; summer: $175.3 \pm 4.0 \mathrm{~mm}$ respectively; $t_{26.2}=$ $0.55, P=0.59)$. For adult females, there was no sig- 


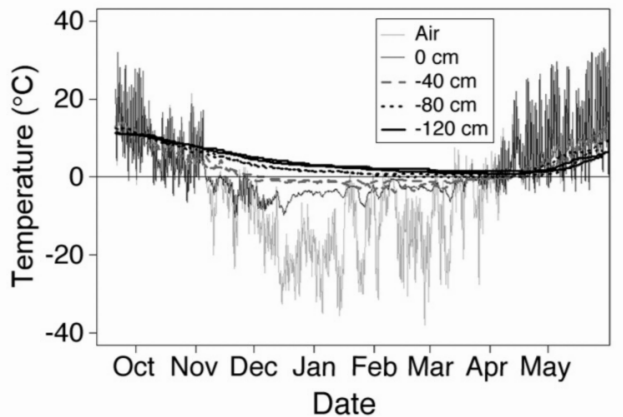

Figure 6. Mean temperatures from iButtons ${ }^{\circledR}$ placed at five den sites at Souris River Bend Wildlife Management Area over winter (20 September-22 May) in 2007-2008 and 20082009. Separate lines are shown for each winter; air temperature and surface temperature $(0 \mathrm{~cm})$ were only recorded in 2008-2009.

nificant difference in tail or head length (Table 4) for individuals captured at the hibernation site compared to those captured at summer sites. Adult females at the hibernation site had wider heads than those from summer sites (Table 4). For adult males, there was no significant difference in tail length, head width, or head length (Table 4) for individuals captured at the hibernation site compared to those captured at summer sites. Both adult females (Table 4; Figure 3b) and adult males (Table 4; Figure 3d) were significantly heavier for their body size at summer sites compared to the hibernation site.

\section{Discussion}

Our study examined demography, morphology, reproduction, habitat use, and hibernation in populations of $S$. occipitomaculata in southwestern Manitoba. This area is relatively arid and has an average daily temperature across the year of only $2.2^{\circ} \mathrm{C}$ (Environment Canada 2016). This is a stressful environment, but the explosive productivity of summer may be enough to compensate (Tuttle and Gregory 2014). Variation between populations we observed and other parts of this species' range may indicate how they make up for this stress.

The demographics of $S$. occipitomaculata were similar to the findings of Blanchard (1937) with adults accounting for the vast majority of observations. We suspect this may simply reflect the difficulty of finding juveniles using walking surveys. When using funnel traps at hibernation sites we collected more YOY and juveniles. However, Semlitsch and Moran (1984) also observed adult biased demographics using passive trapping.

Although we observed female biased SSD in this population, differences were not large. Male to female body size ratios were similar to populations from Michigan, Minnesota, and interestingly South Carolina, but less dimorphic than populations in Virginia, Indiana, or Pennsylvania (reviewed in Meshaka and Klippel 2011). Body sizes at our study sites were smaller than most other locales, including other northern populations (Criddle 1937; Meshaka and Klippel 2011). The minimum size of gravid snakes in our study was $154 \mathrm{~mm}$,

TABLE 4. Linear models comparing tail length, head width, head length, and natural log-transformed mass of Red-bellied Snake (Storeria occipitomaculata) between summer and hibernation sites (site variable). Models were done separately for each sex. $\mathrm{SVL}=$ snout-vent length.

\begin{tabular}{|c|c|c|c|c|c|}
\hline Model & Sex & $F$ & $d f$ & $P$ & Adjusted $r^{2}$ \\
\hline tail length $=$ site $+\mathrm{SVL}$ & $\mathrm{F}$ & 0.24 & 2,64 & 0.790 & 0.02 \\
\hline site & & 0.15 & 1,64 & 0.700 & \\
\hline SVL & & 0.58 & 1,64 & 0.570 & \\
\hline site + SVL & $\mathrm{M}$ & 2.13 & 2,31 & 0.140 & 0.06 \\
\hline site & & 0.19 & 1,31 & 0.670 & \\
\hline SVL & & 4.08 & 1,31 & 0.050 & \\
\hline head width $=$ site + SVL & $\mathrm{F}$ & 2.49 & 2,64 & 0.090 & 0.04 \\
\hline site & & 4.61 & 1,64 & 0.040 & \\
\hline SVL & & 0.37 & 1,64 & 0.550 & \\
\hline site + SVL & $\mathrm{M}$ & 7.12 & 2,31 & 0.003 & 0.27 \\
\hline site & & 0.51 & 1,31 & 0.480 & \\
\hline SVL & & 13.72 & 1,31 & $<0.001$ & \\
\hline head length $=$ site + SVL & $\mathrm{F}$ & 5.80 & 2,54 & 0.005 & 0.15 \\
\hline site & & 0.08 & 1,54 & 0.780 & \\
\hline SVL & & 11.52 & 1,54 & 0.001 & \\
\hline site + SVL & $\mathrm{M}$ & 3.78 & 2,25 & 0.040 & 0.17 \\
\hline site & & 0.04 & 1,25 & 0.840 & \\
\hline SVL & & 7.5 & 1,25 & 0.010 & \\
\hline $\log ($ mass $)=$ site + SVL & $\mathrm{F}$ & 36.61 & 2,64 & $<0.001$ & 0.52 \\
\hline site & & 36.77 & 1,64 & $<0.001$ & \\
\hline SVL & & 36.46 & 1,64 & $<0.001$ & \\
\hline site + SVL & M & 21.58 & 2,31 & $<0.001$ & 0.56 \\
\hline site & & 4.50 & 1,31 & 0.040 & \\
\hline SVL & & 38.66 & 1,31 & $<0.001$ & \\
\hline
\end{tabular}


larger than those in South Carolina (Semlitsch and Moran 1984) and similar to Virginia (Mitchell 1994), but smaller than most of the rest of the range (Meshaka and Klippel 2011). The literature suggests, while body size in S. occipitomaculata varies, average clutch sizes are similar across its range. In our study, gravid females had similar clutch sizes to other populations (7-9 young; Meshaka and Klippel 2011). Northern reptiles are often thought to be constrained, having slower growth and delayed maturity relative to southern populations (Atkinson 1994) but this is not always the case (Angilletta et al. 2004; Tuttle and Gregory 2012, 2014). Early maturity is usually accomplished by increased growth to similar minimum size (Tuttle and Gregory 2012, 2014). Storeria occipitomaculata appears to mature at a smaller size in the southeast and northwest portions of its range while maintaining similar clutch sizes to physically larger populations elsewhere.

Although spring breeding has been widely reported in this species (Semlitsch and Moran 1984; Ernst and Ernst 2003; Meshaka and Klippel 2011) the abundance of males in late summer suggests August breeding activity (Blanchard 1937; Trapido 1940; Willson and Dorcas 2004). Although we did not directly observe any fall mating, it has been reported previously in Manitoba (Gregory 1977). Also, we found evidence of primary vitellogenesis pre-hibernation in two road-killed specimens collected in October 2007 and captured gravid females as early as 14 May. In our study, the majority of adult females captured during the summer were gravid (96\%) suggesting annual reproduction similar to populations in the south (Semlitsch and Moran 1984). Reproduction should be limited by available resources (Aldridge 1979) and biennial reproduction appears to be common in northern snakes (Larsen et al. 1993; Gregory 2009). Mating in late summer/fall would provide females with a longer foraging and gestation period that would allow for greater provisioning of offspring in utero and may explain this population's ability to reproduce annually despite the short season. This is likely an important life history trait for a short lived species like S. occipitomaculata (Snider and Bowler 1992).

The habitat use by S. occipitomaculata we observed in Manitoba was similar to that found in Minnesota (Lang 1971) and Illinois (Brown and Phillips 2012) but differed from findings in Kansas (Pisani and Busby 2011). We found disproportionate use of grassland habitat on flat land or with south facing aspects. Pisani and Busby (2011) found the majority of their sample associated with moister habitats avoiding open habitats on north, west, and east slopes, and usually associated with water. These differences may reflect local availability, local adaptation, or perhaps a trade-off made by northern S. occipitomaculata, sacrificing osmotic preferences for thermal ones. This may be compensated for by microhabitat selection. In our study, most captures were under cover $(87 \%)$ and more than half were found under plywood. This pattern may reflect our sampling methods rather than true preferences, although a preference for cover objects is common in small snakes (Halliday and Blouin-Demers 2015; Gregory and Tuttle 2016).

Land-cover use differed across the 10, two week periods of our study. Use of mixedwood forest by $S$. occipitomaculata occurred in spring, while they used roads and grassland most commonly in late summer and fall (at the hibernation site). Semlitsch and Moran (1984) suggested that moisture gradients and food availability drove activity pulses and habitat choice in this species in South Carolina. Alternatively, use of grasslands in late summer may reflect habitat preferences of gravid females, because grasslands are warmer than forest habitats in keeping with the cold climate hypothesis (Tinkle and Gibbons 1977) although we did not observe a sex bias in habitat choice.

Over the course of three years, the first arrival of S. occipitomaculata at hibernation sites was later than other species and was consistently associated with the first frost or nighttime temperatures below freezing similar to Lang (1971). In cold regions such as Minnesota or Manitoba, it is difficult to understand why a small snake would arrive at a hibernaculum so late in the season when hard frosts are likely. Although $S$. occipitomaculata appears to be able to cope with several days of cold weather, a prolonged or particularly hard frost may cause mortality (Lang 1971). Critical thermal minimum $\left(\mathrm{CT}_{\min }\right)$ has not been determined in S. occipitomaculata but ranges from 2.5 to $11.5^{\circ} \mathrm{C}$ in other snake species with body size, species, and latitudinal effects (reviewed in Cox et al. 2018) so it likely above $0^{\circ} \mathrm{C}$. In the smaller Ring-necked Snake (Diadophis punctatus) $\mathrm{CT}_{\min }$ was $11.5^{\circ} \mathrm{C}$ and decreased with increasing body size, suggesting that small individuals require higher $\mathrm{CT}_{\text {min }}$ (Cox et al. 2018).

The use of ant mounds by $S$. occipitomaculata, $O$. vernalis, and T. sirtalis parietalis has been previously reported by Criddle (1937), Carpenter (1953), Lang (1971), and Pisani (2009). These mounds do not offer a thermal advantage over the winter compared to surrounding soil (Scherba 1962). However, due to their insulation and ability to collect solar radiation, these sites are warmer and more stable during the active season (Scherba 1962; Duff et al. 2016), thereby potentially increasing season length. The thermal profiles we generated at the hibernation site indicated stability increases with soil depth but, even at $80 \mathrm{~cm}$, temperatures dipped below freezing. This is similar to the temperature profile generated by Lang (1971), although the frost lines at most of the ant mounds he investigated were slightly deeper, likely due to the shallow water table at our hibernation site. The temperature profile of the mounds suggests that these snakes would have to hibernate near or below the water table (Costanzo 1989 ) which was $\sim 120 \mathrm{~cm}$ in our study. Criddle (1937) found this to be the case when he excavated a mound near Treesbank, Manitoba and found many of the snakes 
at $\sim 144 \mathrm{~cm}$ depth, in contact with the water table. Without these abandoned ant mounds $S$. occipitomaculata, poorly suited to true burrowing with its kinetic skull and large eyes, would be unable to access such thermally stable and humid refuges (Pisani 2009). These sites, or other similar fossorial retreats, are likely critical for the persistence of this species at such northern climates.

Caution must be taken when comparing snapshots of populations' life histories (Seigel and Fitch 1985). There is a great deal of variation reported across the species' range and among individuals, and like Meshaka and Klippel (2011), we found a limited effect of latitude between the population we observed and the rest of the range. This observation adds to our understanding of how this species can survive in an area that is climatically unsuitable for terrestrial activity for much of the year. In this area, this species appears to use relatively warm habitats, rapid reproduction, and abandoned ant nests to persist and thrive. Productive habitats, such as the northern Great Plains, may allow this species to adopt a "fast" lifestyle that favours early maturity and higher than expected annual fecundity, with most females reproducing annually (Tuttle and Gregory 2014). Much remains unknown and future studies should confirm the genetic or environmental underpinning of body size at maturity and clutch size along with local diet, timing of breeding, and the drivers and risks associated with late-season migration for this species.

\section{Acknowledgements}

Thanks to L. Cairns, R. Cairns, B. Cairns, J. Cairns, R. Dale, T. Dempsey, A. Dransfield, N. Gushulak, C. Jaeger, J. Larkin, D. Macintyre, and J. Phillips for their assistance in the field and study design. The Ella MayStewart Perdue Trust Fund, Brandon University Research Committee, Brandon University Student Union Fellowship, and Department of Zoology provided financial support. Thank you to W. Halliday and two anonymous reviewers for their helpful comments to improve the manuscript. All protocols were done with the approval of the Brandon University Animal Care Committee (2006R05) and all necessary permits for field study were obtained (Manitoba Conservation: WB060 82, WB07879, WB09616, and WB11022; Manitoba Parks: 21739, 25035, 25968, and 2011-P-HQ-022).

\section{Literature Cited}

Aldridge, R.D. 1979. Female reproductive cycles of the snakes Arizona elegans and Crotalus viridis. Herpetologica 35: 256-261.

Angilletta, M.J., Jr., T.D. Steury, and M.W. Sears. 2004. Temperature, growth rate, and body size in ectotherms: fitting pieces of a life-history puzzle. Integrative and Comparative Biology 44: 498-509. https://doi.org/10.1093/icb/ 44.6.498

Atkinson, D. 1994. Temperature and organism size: a biological law for ectotherms? Advances in Ecological Research 25: 1-58. https://doi.org/10.1016/S0065-2504(08)60212-3

Berrigan, D., and E.L. Charnov. 1994. Reaction norms for age and size at maturity in response to temperature: a puz- zle for life historians. Oikos 70: 474-478. https://doi.org/ $10.2307 / 3545787$

Blackburn, D.G., K.E. Anderson, A.R. Johnson, S.R. Knight, and G.S. Gavelis. 2009. Histology and ultrastructure of the placental membranes of the viviparous brown snake, Storeria Dekayi (Colubridae: Natricinae). Journal of Morphology 270: 1137-1154. https://doi.org/10.1002/ jmor. 10650

Blanchard, F.N. 1937. Data on the natural history of the redbellied snake, Storeria occipitomaculata (Storer), in Northern Michigan. Copeia 1937: 151-162. https://doi.org/10. $2307 / 1436135$

Blouin-Demers, G., K.A. Prior, and P.J. Weatherhead. 2002. Comparative demography of black rat snakes (Elaphe obsoleta) in Ontario and Maryland. Journal of Zoology 256: 1-10. https://doi.org/10.1017/S0952836902000018

Blouin-Demers, G., and P.J. Weatherhead. 2001. Thermal ecology of black rat snakes (Elaphe obsoleta) in a thermally challenging environment. Ecology 82: 3025-3043. https:// doi.org/10.1890/0012-9658(2001)082[3025:TEOBRS] 2.0.CO;2

Brown, E.E. 1979. Stray food records from New York and Michigan snakes. American Midland Naturalist 102: 200203. https://doi.org/10.2307/2425088

Brown, L.E., and C.A. Phillips. 2012. Distribution, habitat, and zoogeography of the semifossorial red-bellied snake Storeria occipitomaculata (Storer) in Illinois. Illinois Natural History Survey Bulletin 39: 297-322.

Carpenter, C.C. 1953. A study of hibernacula and hibernating associations of snakes and amphibians in Michigan. Ecology 34: 74-80. https://doi.org/10.2307/1930310

Cook, F.R. 1984. Introduction to Canadian Amphibians and Reptiles. National Museum of Natural Sciences, National Museums of Canada, Ottawa, Ontario, Canada.

Costanzo, J.P. 1989. Effects of humidity, temperature, and submergence behavior on survivorship and energy use in hibernating garter snakes, Thamnophis sirtalis. Canadian Journal of Zoology 67: 2486-2492. https://doi.org/10.11 39/z89-351

Cox, R.M., M.A. Butler, and H.B. John-Alder. 2007. The evolution of sexual size dimorphism in reptiles. Pages 3849 in Sex, Size and Gender Roles: Evolutionary Studies of Sexual Size Dimorphism. Edited by D.J. Fairbairn, W.U. Blanckenhorn, and T. Székely. Oxford University Press, New York, New York, USA. https://doi.org/10.1093/acprof :oso/9780199208784.003.0005

Cox, C.L., M.L. Logan, O. Bryan, D. Kaur, E. Leung, J. McCormack, J. McGinn, L. Miller, C. Robinson, J. Salem, J. Scheid, T. Warzinski, and A.K. Chung. 2018. Do ring-necked snakes choose retreat sites based upon thermal preferences? Journal of Thermal Biology 71: 232-236. https://doi.org/10.1016/j.jtherbio.2017.11.020

Criddle, S. 1937. Snakes from an ant hill. Copeia 1937: 142. https://doi.org/10.2307/1436960

Duff, L.B., T.M. Urichuk, L.N. Hodgins, J.R. Young, and W.A. Untereiner. 2016. Diversity of fungi from the mound nests of Formica ulkei and adjacent non-nest soils. Canadian Journal of Microbiology 62: 562-571. https://doi.org/ 10.1139/cjm-2015-0628

Environment Canada. 2016. National Climate Data and Information Archive, Environment Canada. Accessed 18 May 2018. https://tinyurl.com/ya5pe4cl.

Ernst, C.H., and E.M. Ernst. 2003. Snakes of the United States and Canada. Smithsonian Books, Washington, DC, USA. 
ESRI. 2011. ArcGIS Desktop. Redlands, California, USA.

Fitch, H.S. 1981. Sexual size differences in reptiles. University of Kansas Museum of Natural History Miscellaneous Publications 70: 1-72.

Fitch, H.S. 1987. Collecting and life-history techniques. Pages 143-164 in Snakes: Ecology and Evolutionary Biology. Edited by R.A. Seigel, J.T. Collins, and S.S. Novak. Macmillan, New York, New York, USA.

Gienger, C.M., and D.D. Beck. 2011. Northern Pacific Rattlesnakes (Crotalus oreganus) use thermal and structural cues to choose overwintering hibernacula. Canadian Journal of Zoology 89: 1084-1090. https://doi.org/10.1139/z11086

Gregory, P.T. 1977. Life history observations of three species of snakes in Manitoba. Canadian Field-Naturalist 91: 19 27. Accessed 11 November 2018. https://biodiversitylibrary. org/page/28061222.

Gregory, P.T. 2009. Northern lights and seasonal sex: the reproductive ecology of cool-climate snakes. Herpetologica 65: 1-13. https://doi.org/10.1655/0018-0831-65.1.1

Gregory, P.T., and K.N. Tuttle. 2016. Effects of body size and reproductive state on cover use of five species of temperate-zone Natricine snakes. Herpetologica 72: 64-72. https://doi.org/10.1655/HERPETOLOGICA-D-15-00021

Halliday, W.D., and G. Blouin-Demers. 2015. Efficacy of coverboards for sampling small northern snakes. Herpetology Notes 8: 309-314.

Harvey, D.S., and P.J. Weatherhead. 2006a. Hibernation site selection by Eastern Massasauga Rattlesnakes (Sistrurus catenatus catenatus) near their northern range limit. Journal of Herpetology 40: 66-73. https://doi.org/10.1670/8905A.1

Harvey, D., and P.J. Weatherhead. 2006b. A test of the hierarchical model of habitat selection using eastern massasauga rattlesnakes (Sistrurus c. catenatus). Biological Conservation 130: 206-216. https://doi.org/10.1016/j.biocon. 2005.12.015

Kiester, A.R. 1971. Species density of North American amphibians and reptiles. Systematic Biology 20: 127-137. https://doi.org/10.2307/2412053

King, R.B. 1993. Determinants of offspring number and size in the brown snake, Storeria dekayi. Journal of Herpetology 27: 175-185. https://doi.org/10.2307/1564934

Lang, J.W. 1969. Hibernation and movements of Storeria occipitomaculata in northern Minnesota. Journal of Herpetology 3: 196-197.

Lang, J.W. 1971. Overwintering of three species of snakes in northwestern Minnesota. M.Sc. thesis, University of North Dakota, Grand Forks, North Dakota, USA

Larsen, K.W., P.T. Gregory, and R. Antoniak. 1993. Reproductive ecology of the common garter snake Thamnophis sirtalis at the northern limit of its range. American Midland Naturalist 129: 336-345. https://doi.org/10.2307/242 6514

Manitoba Land Initiative. 2012. Manitoba Conservation and Water Stewardship. Accessed 5 February 2012. https://mli 2.gov.mb.ca.

Meshaka, W.E., and A.N. Klippel. 2011. Seasonal activity, reproduction, and growth of the Northern Redbelly Snake, Storeria occipitomaculata occipitomaculata (Storer, 1839), from Pennsylvania. Journal of Kansas Herpetology 37: 1620.

Mitchell, J.C. 1994. The Reptiles of Virginia. Smithsonian Institution Press, Washington, DC, USA.
Pisani, G. 2009. Use of an active ant nest as a hibernaculum by small snake species. Transactions of the Kansas Academy of Science. Kansas Academy of Science 112: 113-118. https://doi.org/10.1660/062.112.0215

Pisani, G.R., and W.H. Busby. 2011. Ecology of the Smooth Earth Snake (Virginia valeriae) and Redbelly Snake (Storeria occipitomaculata) in Northeastern Kansas. Kansas Biological Survey, Lawrence, Kansas, USA.

R Development Core Team. 2017. R: A language and environment for statistical computing. R Foundation for Statistical Computing, Vienna, Austria.

Scherba, G. 1962. Mound temperatures of the ant Formica ulkei Emery. American Midland Naturalist 67: 373-385. https://doi.org/10.2307/2422715

Seigel, R.A., and H.S. Fitch. 1985. Annual variation in reproduction in snakes in a fluctuating environment. Journal of Animal Ecology 54: 497-505. https://doi.org/10.2307/4494

Semlitsch, R.D., and G.B. Moran. 1984. Ecology of the redbelly snake (Storeria occipitomaculata) using mesic habitats in South Carolina. American Midland Naturalist 111: 33-40. https://doi.org/10.2307/2425539

Shine, R. 1994. Sexual size dimorphism in snakes revisited. Copeia 1994: 326-346. https://doi.org/10.2307/1446982

Shine, R., J. Webb, A. Lane, and R. Mason. 2006. Flexible mate choice: a male snake's preference for larger females is modified by the sizes of females encountered. Animal Behaviour 71: 203-209. https://doi.org/10.1016/j.anbehav. 2005.04.005

Snider, A.T., and J.K. Bowler. 1992. Longevity of reptiles and amphibians in North American collections. Herpetological Circulars No. 21. Society for the Study of Amphibians and Reptiles Publications, Lawrence, Kansas, USA.

Tinkle, D.W., and J.W. Gibbons. 1977. The distribution and evolution of viviparity in reptiles. Miscellaneous Publications, Museum of Zoology, University of Michigan 154: $1-55$.

Trapido, H. 1940. Mating time and sperm viability in Storeria. Copeia 1940: 107-109. https://doi.org/10.2307/1439 051

Trapido, H. 1944. The snakes of the genus Storeria. American Midland Naturalist 31: 1-84. https://doi.org/10.2307/242 1382

Tuttle, K.N., and P.T. Gregory. 2012. Growth and maturity of a terrestrial ectotherm near its northern distributional limit: does latitude matter? Canadian Journal of Zoology 90: 758-765. https://doi.org/10.1139/z2012-044

Tuttle, K.N., and P.T. Gregory. 2014. Reproduction of the Plains Garter Snake, Thamnophis radix, near its northern range limit: more evidence for a "fast" life history. Copeia 2014: 130-135. https://doi.org/10.1643/CH-13-119

Weatherhead, P.J., J.H. Sperry, G.L.F. Carfagno, and G. Blouin-Demers. 2012. Latitudinal variation in thermal ecology of North American ratsnakes and its implications for the effect of climate warming on snakes. Journal of Thermal Biology 37: 273-281. https://doi.org/10.1016/j.j therbio.2011.03.008

Willson, J.D., and M.E. Dorcas. 2004. Aspects of the ecology of small fossorial snakes in the western Piedmont of North Carolina. Southeastern Naturalist 3: 1-12. https://doi.org/ 10.1656/1528-7092(2004)003[0001:AOTEOS]2.0.CO;2

Wright, A.H., and A.A. Wright. 1957. Handbook of Snakes of the United States and Canada. Cornell University Press, Ithaca, New York, USA.

Received 2 March 2018

Accepted 25 May 2018 


\section{SUPPlementary MATERial:}

TABle S1. Numbers of Red-bellied Snake (Storeria occipitomaculata) in three age classes (young-of-year [YOY], juvenile, adult) for each sex that were captured during summer surveys 2007-2009 at Spruce Woods Provincial Park (SWPP), Assiniboine Corridor Wildlife Management Area (ACWMA), Oak Lake, and Canadian Forces Base (CFB) Shilo.

TABLE S2. Number of captures, recaptures, and dead animals for individuals captured at the hibernation site (Souris River Bend Wildlife Management Area) during spring and fall surveys 2007-2010. 